\title{
Immediate and Transgenerational Regulation of Plant Stress Response through DNA Methylation
}

\author{
A. R. Khan ${ }^{1}$, S. M. Shah ${ }^{1} \&$ M. Irshad ${ }^{1}$ \\ ${ }^{1}$ Department of Environmental Sciences, COMSATS Institute of Information Technology, Abbottabad, Pakistan \\ Correspondence: M. Irshad, Department of Environmental Sciences, COMSATS Institute of Information \\ Technology, Abbottabad, Pakistan. E-mail: mirshad@ciit.net.pk
}

Received: January 18, 2014 Accepted: February 11, 2015 Online Published: March 15, 2015

doi:10.5539/jas.v7n4p144 URL: http://dx.doi.org/10.5539/jas.v7n4p144

\begin{abstract}
Epigenetics refers to the heritable changes in gene activity without altering the DNA sequence. DNA methylation along with other epigenetic mechanisms is involved in the chromatin remodeling. This remodeling, especially in plants, plays an important role in the activation or silencing of specific genes as well as other genomic regions in response to the developmental and environmental clues. Environmental clues, biotic and abiotic stresses trigger the shift in the site specific as well as genome wide DNA methylation patterns which influences the plant response to these situations through gene regulation. Therefore, it is of prime importance to analyze variation in the DNA methylation pattern under stress conditions. This review summarizes the topic of DNA methylation by providing the basic/conceptual knowledge and some cases of DNA methylation shift due to stresses.
\end{abstract}

Keywords: epigenetics, biotic and abiotic stresses, locus specific DNA methylation, genome-wide DNA methylation

\section{Epigenetic Modification in Plants}

Chromatin is a complex structure of nucleoproteins, which packs DNA in a highly organized way to fit it into the nucleus of a eukaryotic cell. The nucleosome is the fundamental unit of chromatin which is composed of 147 base pairs of DNA, wrapped around a core of eight histone protein molecules (Grunstein, 1997; Kornberg, 1977). Since the tight packing of DNA in the nucleosome can cause problem of accessibility of DNA by transcription factors and RNA polymerases, the static nature of this complex might not be so desirable. Interestingly, the nucleosome packaging is dynamic in nature and can be subjected to alteration depending upon the environmental or developmental clues (Narlikar et al., 2002), ultimately leading to the regulation of the processes such as transcription, recombination, DNA repair etc. This manipulation of dynamic chromatin provides an additional layer of information, resulting in the modifications of cell/tissue activities through gene regulation causing the shift in various processes like from seed germination to organogenesis, root and shot growth, flowering, embryo formation, as well as response to abiotic and biotic stresses (Roudier et al., 2011). Various mechanisms play an important role in regulation of the chromatin context to control gene expression. Among these mechanisms, epigenetic modifications have caught the interest of many researchers in recent decades.

Epigenetic modifications involves the heritable changes in the gene activities that are mitotically and/or meiotically transmissible without changing the DNA sequence (Holliday, 1994). It is important to mention at this point that the reversible developmental modifications that are involved in the molecular responses (phenotypic plasticity etc.) to environmental changes are not included into epigenetics. They can rather be called as non-heritable chromatin modifications. As supported by many examples, the heritable chromatin modifications (epigenetic modifications) can be classified into mitotically transmissible modifications (reset in the next generation) and meioticallytransgenerational chromatin modifications (inherited/transmitted to the generations) (Cubas et al., 1999; Khan et al., 2013; Lauria et al., 2004; Manning et al., 2006; Zemach et al., 2010a).

Various epigenetic mechanisms like DNA methylation and post-translational covalent histone modifications (e.g. acetylation, ubiquitination, methylation, phosphorylation), non-coding RNAs along with chromatin remodeling enzymes are involved in the chromatin modification (Berger, 2007; Kouzarides, 2007; Rapp \& Wendel, 2005). Out of these, DNA methylation is the best understood and (based on the previous information) considered as the most stable form of epigenetic modifications. Since DNA methylation is the main focus of this review, other 
epigenetic modifications will not be discussed.

\section{DNA Methylation}

A chemical modification in the genomic DNA, which is caused when a methyl group is attached at a specific nucleotide base, is known as DNA methylation. The nucleotide base, which couldtake part in DNA methylation, is either cytosine or adenine but most studied, is methylation at cytosine. When the methyl group (-CH3) is attached at 5 carbon of cytosine then it is termed as 5 -methycytosine and is denoted as $5 \mathrm{mC}$. It is historically ancient and with few exceptions, it has been reported in all major groups of eukaryotes (plant, animals and fungi) (Chan et al., 2005; Goll \& Bestor, 2005; Henderson \& Jacobsen, 2007; Klose \& Bird, 2006; Law \& Jacobsen, 2010).

a)

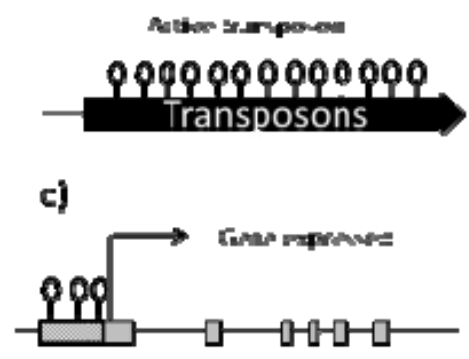

b)

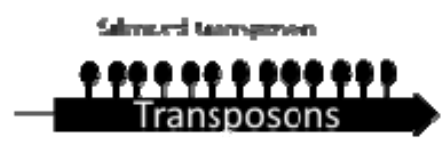

d)

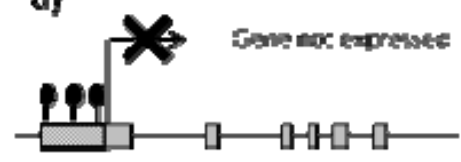

e)

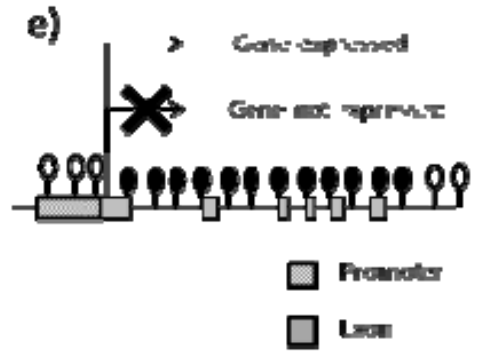

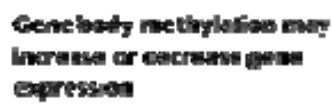

expresesta

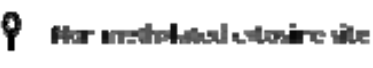

5 mothloponite the

Figure 1. Influence of DNA methylation on gene transposon regulation. a) Transposon in active state due to absence/removal of DNA methylation. b) Transposon in the silence state due to the presence of DNA methylation. c) The gene is expressed in the absence of DNA methylation at the promoter d) DNA methylation at the promoter caused gene silencing. e) Function of gene body methylation is unclear, i.e. depending upon the case study it enhances transcription or it reduces transcription

In plant, different methyltransferase enzymes are responsible for maintenance of DNA methylation. CG methylation is principally maintains by DNA METHYLTRANSFERASE 1 (MET1). MET1 is homologue of mammalian DNA METHYLTRANSFERASE 1 (DNMT1). CHG methylation is maintained by a plant specific CHROMOMETHYASE 3 (CMT3) (Chan et al., 2005). Asymmetric nature of CHH sites needs a complex phenomenon for the maintenance. Plant-specific RNA-dependent DNA Methylation (RdDM) pathway alongwith the de novo methyltransferase DOMAINS REARRANGED METHYLTRANSFERASE 2 (DRM2) help to reacquired de novo methylation after each replication (Law \& Jacobsen, 2010).

5-methylcytosine is mainly characterized in three contexts: $\mathrm{CG}, \mathrm{CHG}$ and $\mathrm{CHH}$ (where $\mathrm{H}$ can be replaced by any base other than G) (Law \& Jacobsen, 2010). Plants and animals show different patterns of DNA methylation. In plants, it can occur at all three contexts i.e. at CG, CHG and CHH sites, where as in animals it is mostly reported at CG site (Feng et al., 2010; Zemach et al., 2010b). The pattern of DNA methylation in plants is mainly understood through the studies in model plant Arabidopsis. The occurrence of 5-methylcitosines is not even when compared on the basis of three contexts. The genome-wide DNA methylation studies on Arabidopsis revealed that DNA methylation levels at $\mathrm{CG}, \mathrm{CHG}$ and $\mathrm{CHH}$ are $24 \%, 6.7 \%$ and $1.7 \%$ respectively. In eukaryotes, DNA methylation occurs in transposable elements as well as in the genes. The extent of DNA methylation depends upon the region of the genome where it occurs. The studies have shown that DNA methylation heavily occurs in transposons and repetitive elements (in all the contexts: $\mathrm{CG}, \mathrm{CHG}$ and $\mathrm{CHH}$ ), and is associated with silencing of these regions (Figure 1), thus playing important role in genome stability (Goll \& Bestor, 2005; Henderson \& Jacobsen, 2007). 
Although, DNA methylation is also associated with gene regulation but the occurrence as well as regulation pattern of DNA methylation in genes depends on the regions within the gene where it occurs (Figure 1). It has negative correlation with the gene expression, if the promoter region is methylated (Zhang et al., 2006). DNA methylation may also occurred within the body of the genes but absent at the start and ends of the gene and provides a bell shaped pattern (known as gene body methylation) (Li et al., 2012; Zemach et al., 2010b). Although this gene body methylation is evolutionarily conserved but the function of DNA methylation within a gene is not yet fully understood (Takuno \& Gaut, 2013; Zhang et al., 2010). The review of various studies in this field suggests that it can be positively as well as negatively associated with gene expression. The understanding of various techniques to study these DNA methylation patterns is important.

\section{DNA Methylation and Plant Stress Response}

DNA methylation, like other epigenetic modifications, is more dynamic than DNA sequence mutations thus they could play essential role in an organism's first response towards changing environment. Therefore studying the variation in the DNA methylation pattern due to variation in environmental condition to regulate the gene expression has become an area of great interest. Grouped according to different stresses, we provide various examples of such studies (especially in crop plants as they are economically and socially important for human survival) (Table 1).

\subsection{Salinity}

In wheat, shift in the DNA methylationdue to salinity stress, in salinity tolerant cultivar and its salinity sensitive progenitor, has been recently reported (Wang et al., 2014). Salt stress induced shift in DNA methylation in both the promoter and coding regions of some of the 24 selected genes, but only the former were associated with changes in transcript (Wang et al., 2014). Similarly, in another study where two cultivars with different level of salt tolerances were evaluated, dose dependent genome-wide DNA hypomethylation was observed in salt stress conditions (Zhong et al., 2009).

In maize, shift in DNA methylation pattern in response to osmotic and salt stress was studied. It was reported that the osmotic stress-induced methylation of retrotransposons. In addition, salt stress induced DNA methylation which caused down regulation of $z m P P 2 C$ gene expression, which is a negative regulator of the stress response, as well as salinity caused a demethylation that had up regulated the zmGST gene expression, which is a positive effecter of the stress response (Tan, 2010).

A set of diverse rice genotypes was analyzed at genome-wide level under salt stress conditionswith the help of MSAP technique. The results revealed a differential methylation pattern in salt stress related gene which lead to the shift of expression of these genes. This differential pattern was also observed in retrotransposons and chromatin modifier genes indicating the involvement of epigenetic markers in stress response (Karan et al., 2012).

Soya bean is an important member of oil seed group. Alteration in DNA methylation profile under salinity stress condition has been observed in soya bean. A significant correlation was observed between shift in DNA methylation pattern under salt stress and gene expression of four genes in this species. The expression profile of one MYB (Myeloblastosis), one b-ZIP (basic leucine zipper) and two AP2/DREB genes showed differential expression associated with DNA hypomethylation in promoter or coding region under salt stress conditions (Song et al., 2012).

In mangrove plants, a comparative study was carried out. The plant from two different habitats i.e. salt marsh neighborhood and riverside habitat were compared on morphological basis (Lira-Medeiros et al., 2010). The result revealed that the plant growing in riverside were much taller and thicker than those grown in salt marsh neighborhood. Hypermethylation was observed in river side plant on analysis of genome wide DNA methylation with the help of MSAP technique. These results suggested that environmental adaptation will lead to epigenetic variation (Lira-Medeiros et al., 2010). Dyachenko et al. (2006) reported that Mesembryanthemum crystallinum plants, when subjected to high saline condition, hypermethylation at CHG methylation in nuclear genome was observed.

\subsection{Drought}

DNA methylation at genome-wide level was studied under drought conditions in rice. This study compared the variation of DNA methylation pattern under drought and subsequent recovery from it. The results showed that most DNA methylation modifications reversed after the recovery but some were maintained. This indicated that plant may have a mechanism of some sort to remember the previous condition under which it was subjected during 
its life cycle. This study also demonstrated that environmental stress leads to induced epigenetic variation which play an important role for adaptation of rice or other plant under diverse conditions (Wang et al., 2011).

Table 1. DNA methylation modifications involved in biotic and abiotic stress

\begin{tabular}{|c|c|c|c|c|c|}
\hline Sr. No. & Plant species & Stress & Genomic region & Mode of action & References \\
\hline \multirow{4}{*}{1} & \multirow{4}{*}{ Wheat } & Salinity & 24 genes & $\begin{array}{l}\text { Stress induced shift in DNA } \\
\text { methylation }\end{array}$ & (Wang et al., 2014) \\
\hline & & Salinity & Genome-wide & Hypomethylation & (Zhong et al., 2009) \\
\hline & & Cold treatment & $V R N-A 1$ & Site specific Hypermethylation & (Khan et al., 2013) \\
\hline & & Cold treatment & Genome-wide & Demethylation & (Sherman \& Talbert, 2002) \\
\hline \multirow{5}{*}{2} & \multirow{5}{*}{ Maize } & Cold stress & $Z m M I 1$ & Root-specific hypomethylation & (Steward et al., 2002) \\
\hline & & Cold stress & Genome-wide & $\begin{array}{l}\text { Global methylation shift. Mainly } \\
\text { demethylation of fully methyated } \\
\text { fragments }\end{array}$ & (Shan et al., 2013) \\
\hline & & Osmotic & Transposon region & Hypermethylation & (Tan, 2010) \\
\hline & & Salt Stress & Root zmPP2C & Hypermethylation & (Tan, 2010) \\
\hline & & Salt Stress & Leaf zmGST & Hypomethylation & (Tan, 2010) \\
\hline \multirow[t]{2}{*}{3} & \multirow[t]{2}{*}{ Rice } & Salinity & Genome-wide & $\begin{array}{l}\text { Differential methylation of salt } \\
\text { stress-related genes, } \\
\text { retrotransposons and chromatin } \\
\text { modifier genes }\end{array}$ & (Karan et al., 2012) \\
\hline & & Drought & Genome-wide & $\begin{array}{l}\text { Genotype dependent differential } \\
\text { methyation }\end{array}$ & (Wang et al., 2011) \\
\hline \multirow{2}{*}{4} & \multirow{2}{*}{ Tomato } & \multirow{2}{*}{ Drought } & Asr 2 & $\begin{array}{l}\text { CHH hypomethylation in } \\
\text { regulatory region }\end{array}$ & (González et al., 2013) \\
\hline & & & Asrl & $\begin{array}{l}\mathrm{CG} \text { hypermethylation and } \mathrm{CHH} \\
\text { hypomethylation }\end{array}$ & (González et al., 2011) \\
\hline \multirow[t]{2}{*}{5} & \multirow[t]{2}{*}{ Soybean } & \multirow[t]{2}{*}{ Salinity } & $\begin{array}{l}\text { Glymallg02400 } \\
\text { (Promoter) }\end{array}$ & $\begin{array}{l}-518 \text { to }-274 \text { cytosines were } \\
\text { demethylated following exposure } \\
\text { to salinity stress for } 1-24 \mathrm{~h}\end{array}$ & (Song et al., 2012) \\
\hline & & & $\begin{array}{l}\text { Glymal6g27950 } \\
\text { (Promoter) }\end{array}$ & $\begin{array}{l}\text { Hypomethylation at transcription } \\
\text { start codon }(-24 \text { to }-233)\end{array}$ & (Song et al., 2012) \\
\hline 6 & Mangrove & Salinity & Genome-wide & Global hypomethylation & (Lira-Medeiros et al., 2010) \\
\hline 7 & $\begin{array}{l}\text { Mesembryanthem } \\
\text { um crystallinum }\end{array}$ & Salinity & Genome-wide & CHG hypermethylation & (Dyachenko et al., 2006) \\
\hline \multirow{2}{*}{8} & \multirow{2}{*}{ Tobacco } & $\begin{array}{l}\text { Aluminium, } \\
\text { Salt and cold }\end{array}$ & $N t G P D L$ & Hypomethylation & (Choi \& Sano, 2007) \\
\hline & & $\begin{array}{l}\text { Tobacco } \\
\text { Mosaic Virus }\end{array}$ & NtAlix 1 & Hypermethylation & (Wada et al., 2004) \\
\hline
\end{tabular}

Some work regarding DNA methylation shift in response to stresses has been done in Tomato. Tomato plants are analyzed for DNA methylation pattern under drought condition and it was observed that Abscisic Acid Stress Ripening1 (Asrl) gene showed CHH hypomethylationunder more water stress conditions and due to this hypomethylation, an increase in Asrl gene expression was observed (González et al., 2011). Along with Asrl, DNA methylation at Abscisic Acid Stress Ripening1 (Asr2) gene was also reported in its regulatory region at all three contexts of DNA methylation (CG, $\mathrm{CHG} \mathrm{CHH}$ ). Interestingly the gene body methylation was only observed for one context (CG). The site-specific removal of methyl marks from $\mathrm{CHH}$ sites in the regulatory region was observed under drought stress. The $A s r 2$ response is heritable and observed generation after generation. The $A s r 2$ 
is thought to have evolutionary importance(González et al., 2013).

\subsection{Cold Stress and Cold Treatment}

In response to cold treatment (vernalization), site specific DNA hypermethylation has been recently reported (Khan et al., 2013). In this study, the DNA methylation profile of $V R N-A 1$ gene was studied in winter wheat and differential pattern of methylation at non-CG sites was reported. The CG sites remained unaffected by the treatment while $\mathrm{CHG}$ and $\mathrm{CHH}$ sites within specific region of intron-1 of $V R N-A 1$ gene showed an increased due to the cold treatment. At genome-wide level, Sherman and Talbert (2002) compared Near-Isogenic Lines (NILs) for winter and spring wheat alongwith vernalized (cold treatment) and non-vernalized condition for DNA methylation variations. They reported that winter wheat was more methylated as compared to spring wheat and the vernalization (cold treatment) induced demethylation compared to non-vernalized plants (Sherman \& Talbert, 2002).

There are some studies in maize also showing a shift in DNA methylation due to cold stress. In one study, DNA methylation pattern of maize was studies in cold stress at seedling stage. A fragment was identified which was only expressed under cold stress and was named as ZmMII. The results indicate that DNA methylation leads to differential gene expression by altering the chromatin structure and was under control of environmental stress (Steward et al., 2002). Genome-wide DNA methylation under cold stress was also investigatedby using Methylation-sensitive amplificationpolymorphism (MSAP) technique. The result was global shift in DNA methylation due to demethylation of fully methylated fragments (Shan et al., 2013).

\subsection{Biotic Stress}

Apart from abiotic stress, a changing pattern on DNA methylation was also observed under biotic stress. The tobacco plant was investigated for pathogenic response under the infection of tobacco mosaic virus (TMV). This study revealed DNA hypermethylation at NtAlixl (Nicotiana ALG-2 Interacting protein X 1) gene after 24 hrs. of inoculation and a close relation was observed between DNA methylation shift and activation of stress response genes (Wada et al., 2004).

\subsection{Transgenerational Stress Response}

Because heritability determines the potential of evolutionary changes of a trait, it is essential to determine the degree of heritability of epigenetic modifications, their impact on given ecologically important traits (Falconer \& Mackay, 1996; Fisher, 1930), and their role in individual adaptation to changing environment (Hoffmann \& Sgrò, 2011; Visser, 2008). Although the epigenetic modifications were initially thought to be reversed in next generation, new investigations have revealed the ability of epigenetic modifications caused by stresses to be transgenerationally transmissible. Some of the examples are reviewed here (Table 2):

Table 2. Transgenerational inheritance of DNA methylation shift due to biotic and abiotic stress

\begin{tabular}{|c|c|c|c|c|c|}
\hline Sr. No. & Plant species & Stress & Genomic region & Mode of action & References \\
\hline 1 & Rice & Heavy metal stress & TE \& protein coding genes & $\begin{array}{l}\text { Hypomethylation } \\
\text { at } \mathrm{CHG} \text { sites }\end{array}$ & (Ou et al., 2012) \\
\hline 2 & Arabidopsis & Combined stress & Genome-wide & Hypomethylation & (Boyko et al., 2010) \\
\hline 3 & Tobacco & Tobacco Mosaic Virus & $\begin{array}{l}\text { Genome-wide \& disease } \\
\text { resistance gene-like loci }\end{array}$ & Hypermethylation & (Boyko et al., 2007) \\
\hline
\end{tabular}

Recently transgenerational inheritance of modifications in DNA methylation due to heavy metal stress has been reported in rice. Ou et al. (2012) observed that heavy metal stress caused hypomethylation at CHG sites. These modifications were heritable over three studied generations and this heritability induced tolerance in these generations.In an interesting study, where Arabidopsis plants were exposed to various stresses, like, cold, heat, UVC salt, and flood, the untreated progeny of these plants showed higher tolerance to stress, higher homologous recombination frequency and genomic hypomethylation (Alex Boyko et al., 2010).

In tobacco, it has been shown that the progeny of plants infected with tobacco mosaic virus (TMV) exhibited a high frequency of rearrangements at disease resistance gene-like loci, global genome hypermethylation, and locus-specific hypomethylation (Alexander Boyko et al., 2007). The above mentioned examples (Tables 1-2) are a good source to understand the importance of epigenetic mechanisms in plant under environmental variations and plant adaptation in these conditions. In this respect, the reported data sets of various plant methylomes could 
provide the basis for the selection of differential epigenetic regions as probable targets for better understanding the molecular pathways involved in them and use them for the genetic manipulation for crop improvement.

\section{Summary}

DNA methylation is an epigenetic marker which is involved in the gene regulation as well as genome stability through transponson silencing. The modification in the DNA methylation can occur in response to environmental variations (biotic and abiotic stresses). The examples of the methylation shift, due to stresses which ultimately leads to plant response through gene regulations, provided (in this review) will help in understanding an overall pattern in plant stress responses. Overall this review will help new researchers of plant epigenetics to get an overview of the DNA methylation in terms of basic concepts and their role in plant stress response.

\section{References}

Berger, S. L. (2007). The complex language of chromatin regulation during transcription. Nature, 447, 407-412. http://dx.doi.org/10.1038/nature05915

Boyko, A., Blevins, T., Yao, Y., Golubov, A., Bilichak, A., Ilnytskyy, Y., ... Kovalchuk, I. (2010). Transgenerational Adaptation of Arabidopsis to Stress Requires DNA Methylation and the Function of Dicer-Like Proteins. PLoS ONE, 5, e9514. http://dx.doi.org/10.1371/journal.pone.0009514

Boyko, A., Kathiria, P., Zemp, F. J., Yao, Y., Pogribny, I., \& Kovalchuk, I. (2007). Transgenerational changes in the genome stability and methylation in pathogen-infected plants: (virus-induced plant genome instability). Nucleic Acids Research, 35, 1714-1725. http://dx.doi.org/10.1093/nar/gkm029

Chan, S. W. L., Henderson, I. R., \& Jacobsen, S. E. (2005). Gardening the genome: DNA methylation in Arabidopsis thaliana. Nature Reviews. Genetics, 6, 351-360. http://dx.doi.org/10.1038/nrg1601

Choi, C.-S., \& Sano, H. (2007). Abiotic-stress induces demethylation and transcriptional activation of a gene encoding a glycerophosphodiesterase-like protein in tobacco plants. Molecular Genetics and Genomics, 277, 589-600. http://dx.doi.org/10.1007/s00438-007-0209-1

Cubas, P., Vincent, C., \& Coen, E. (1999). An epigenetic mutation responsible for natural variation in floral symmetry. Nature, 401, 157-161. http://dx.doi.org/10.1038/43657

Dyachenko, O. V., Zakharchenko, N. S., Shevchuk, T. V., Bohnert, H. J., Cushman, J. C., \& Buryanov, Y. I. (2006). Effect of hypermethylation of CCWGG sequences in DNA of Mesembryanthemum crystallinum plants on their adaptation to salt stress. Biokhimiia, 71, 461-465. http://dx.doi.org/10.1134/S000629790604016X

Falconer, D. S., \& Mackay, T. F. C. (1996). Introduction to Quantitative Genetics (4th ed.). Benjamin Cummings.

Feng, S., Cokus, S. J., Zhang, X., Chen, P.-Y., Bostick, M., Goll, M. G., ... Jacobsen, S. E. (2010). From the Cover: Conservation and divergence of methylation patterning in plants and animals. Proceedings of the National Academy of Sciences, 107, 8689-8694. http://dx.doi.org/10.1073/pnas.1002720107

Fisher, R. A. (1930). The Genetical Theory of Natural Selection. At The Clarendon Press. Retrieved from http://archive.org/details/geneticaltheoryo031631mbp

Goll, M. G., \& Bestor, T. H. (2005). Eukaryotic Cytosine Methyltransferases. Annual Review of Biochemistry, 74, 481-514. http://dx.doi.org/10.1146/annurev.biochem.74.010904.153721

González, R. M., Ricardi, M. M., \& Iusem, N. D. (2011). Atypical epigenetic mark in an atypical location: cytosine methylation at asymmetric $(\mathrm{CNN})$ sites within the body of a non-repetitive tomato gene. $B M C$ Plant Biology, 11, 94. http://dx.doi.org/10.1186/1471-2229-11-94

González, R. M., Ricardi, M. M., \& Iusem, N. D. (2013). Epigenetic marks in an adaptive water stress-responsive gene in tomato roots under normal and drought conditions. Epigenetics: Official Journal of the DNA Methylation Society, 8, 864-872. http://dx.doi.org/10.4161/epi.25524

Grunstein, M. (1997). Histone acetylation in chromatin structure and transcription. Nature, 389, $349-352$. http://dx.doi.org/10.1038/38664

Henderson, I. R., \& Jacobsen, S. E. (2007). Epigenetic inheritance in plants. Nature, 447, $418-424$. http://dx.doi.org/10.1038/nature05917

Hoffmann, A. A., \& Sgrò, C. M. (2011). Climate change and evolutionary adaptation. Nature, 470, $479-485$. http://dx.doi.org/10.1038/nature09670 
Holliday, R. (1994). Epigenetics: An overview. Developmental Genetics, 15, 453-457. http://dx.doi.org/10.1002/dvg.1020150602

Karan, R., DeLeon, T., Biradar, H., \& Subudhi, P. K. (2012). Salt Stress Induced Variation in DNA Methylation Pattern and Its Influence on Gene Expression in Contrasting Rice Genotypes. PLoS ONE, 7, e40203. http://dx.doi.org/10.1371/journal.pone.0040203

Khan, A. R., Enjalbert, J., Marsollier, A.-C., Rousselet, A., Goldringer, I., \& Vitte, C. (2013). Vernalization treatment induces site-specific DNA hypermethylation at the VERNALIZATION-A1 (VRN-A1) locus in hexaploid winter wheat. BMC Plant Biology, 13, 209. http://dx.doi.org/10.1186/1471-2229-13-209

Klose, R., \& Bird, A. (2006). Genomic DNA methylation: The mark and its mediators. Trends in Biochemical Sciences, 31, 89-97. http://dx.doi.org/10.1016/j.tibs.2005.12.008

Kornberg, R. D. (1977). Structure of Chromatin. Annual Review of Biochemistry, 46, 931-954. http://dx.doi.org/10.1146/annurev.bi.46.070177.004435

Kouzarides, T. (2007). Chromatin modifications and their function. Cell, 128, 693-705. http://dx.doi.org/10.1016/j.cell.2007.02.005

Lauria, M., Rupe, M., Guo, M., Kranz, E., Pirona, R., Viotti, A., \& Lund, G. (2004). Extensive maternal DNA hypomethylation in the endosperm of Zea mays. The Plant Cell, 16, 510-522. http://dx.doi.org/10.1105/tpc.017780

Law, J. A., \& Jacobsen, S. E. (2010). Establishing, maintaining and modifying DNA methylation patterns in plants and animals. Nature Reviews Genetics, 11, 204-220. http://dx.doi.org/10.1038/nrg2719

Lira-Medeiros, C. F., Parisod, C., Fernandes, R. A., Mata, C. S., Cardoso, M. A., \& Ferreira, P. C. G. (2010). Epigenetic Variation in Mangrove Plants Occurring in Contrasting Natural Environment. PLoS ONE, 5, e10326. http://dx.doi.org/10.1371/journal.pone.0010326

Li, X., Zhu, J., Hu, F., Ge, S., Ye, M., Xiang, H., ... Wang, W. (2012). Single-base resolution maps of cultivated and wild rice methylomes and regulatory roles of DNA methylation in plant gene expression. $B M C$ Genomics, 13, 300. http://dx.doi.org/10.1186/1471-2164-13-300

Manning, K., Tör, M., Poole, M., Hong, Y., Thompson, A. J., King, G. J., Giovannoni, J. J., \& Seymour, G. B. (2006). A naturally occurring epigenetic mutation in a gene encoding an SBP-box transcription factor inhibits tomato fruit ripening. Nature Genetics, 38, 948-952. http://dx.doi.org/10.1038/ng1841

Narlikar, G. J., Fan, H.-Y., \& Kingston, R. E. (2002). Cooperation between Complexes that Regulate Chromatin Structure and Transcription. Cell, 108, 475-487. http://dx.doi.org/10.1016/S0092-8674(02)00654-2

Ou, X., Zhang, Y., Xu, C., Lin, X., Zang, Q., Zhuang, T., ... Liu, B. (2012). Transgenerational Inheritance of Modified DNA Methylation Patterns and Enhanced Tolerance Induced by Heavy Metal Stress in Rice (Oryza sativa L.). PLoS ONE, 7, e41143. http://dx.doi.org/10.1371/journal.pone.0041143

Rapp, R., \& Wendel, J. (2005). Epigenetics and plant evolution. NEW PHYTOLOGIST, 168, 81-91. http://dx.doi.org/10.1111/j.1469-8137.2005.01491.x

Roudier, F., Ahmed, I., Bérard, C., Sarazin, A., Mary-Huard, T., Cortijo, S., ... Colot, V. (2011). Integrative epigenomic mapping defines four main chromatin states in Arabidopsis. The EMBO Journal, 30, 1928-1938. http://dx.doi.org/10.1038/emboj.2011.103

Shan, X., Wang, X., Yang, G., Wu, Y., Su, S., Li, S., .. Yuan, Y. (2013). Analysis of the DNA methylation of maize (Zea mays L.) in response to cold stress based on methylation-sensitive amplified polymorphisms. Journal of Plant Biology, 56, 32-38. http://dx.doi.org/10.1007/s12374-012-0251-3

Sherman, J., \& Talbert, L. (2002). Vernalization-induced changes of the DNA methylation pattern in winter wheat. Genome, 45, 253-260. http://dx.doi.org/10.1039/G01-147

Song, Y., Ji, D., Li, S., Wang, P., Li, Q., \& Xiang, F. (2012). The Dynamic Changes of DNA Methylation and Histone Modifications of Salt Responsive Transcription Factor Genes in Soybean. PLoS ONE, 7, e41274. http://dx.doi.org/10.1371/journal.pone.0041274

Steward, N., Ito, M., Yamaguchi, Y., Koizumi, N., \& Sano, H. (2002). Periodic DNA Methylation in Maize Nucleosomes and Demethylation by Environmental Stress. Journal of Biological Chemistry, 277, 37741-37746. http://dx.doi.org/10.1074/jbc.M204050200 
Takuno, S., \& Gaut, B. S. (2013). Gene body methylation is conserved between plant orthologs and is of evolutionary consequence. Proceedings of the National Academy of Sciences of the United States of America, 110, 1797-1802. http://dx.doi.org/10.1073/pnas.1215380110

Tan, M. (2010). Analysis of DNA methylation of maize in response to osmotic and salt stress based on methylation-sensitive amplified polymorphism. Plant Physiology and Biochemistry, 48, 21-26. http://dx.doi.org/10.1016/j.plaphy.2009.10.005

Visser, M. E. (2008). Keeping up with a warming world; assessing the rate of adaptation to climate change. Proceedings of the Royal Society B: Biological Sciences, 275, 649-659. http://dx.doi.org/10.1098/rspb.2007.0997

Wada, Y., Miyamoto, K., Kusano, T., \& Sano, H. (2004). Association between up-regulation of stress-responsive genes and hypomethylation of genomic DNA in tobacco plants. Molecular Genetics and Genomics, 271, 658-666. http://dx.doi.org/10.1007/s00438-004-1018-4

Wang, M., Qin, L., Xie, C., Li, W., Yuan, J., Kong, L., ... Liu, S. (2014). Induced and Constitutive DNA Methylation in a Salinity Tolerant Wheat Introgression Line. Plant and Cell Physiology, pcu059. http://dx.doi.org/10.1093/pcp/pcu059

Wang, W.-S., Pan, Y.-J., Zhao, X.-Q., Dwivedi, D., Zhu, L.-H., Ali, J., ... Li, Z.-K. (2011). Drought-induced site-specific DNA methylation and its association with drought tolerance in rice (Oryza sativa L.). Journal of Experimental Botany, 62, 1951-1960. http://dx.doi.org/10.1093/jxb/erq391

Zemach, A., Kim, M. Y., Silva, P., Rodrigues, J. A., Dotson, B., Brooks, M. D., \& Zilberman, D. (2010a). Local DNA hypomethylation activates genes in rice endosperm. Proceedings of the National Academy of Sciences, 201009695. http://dx.doi.org/10.1073/pnas.1009695107

Zemach, A., McDaniel, I. E., Silva, P., \& Zilberman, D. (2010b). Genome-Wide Evolutionary Analysis of Eukaryotic DNA Methylation. Science, 328, 916-919. http://dx.doi.org/10.1126/science.1186366

Zhang, M., Kimatu, J. N., Xu, K., \& Liu, B. (2010). DNA cytosine methylation in plant development. Journal of Genetics and Genomics, 37, 1-12. http://dx.doi.org/10.1016/S1673-8527(09)60020-5

Zhang, X., Yazaki, J., Sundaresan, A., Cokus, S., Chan, S. W.-L., Chen, H., ... Ecker, J. R. (2006). Genome-wide High-Resolution Mapping and Functional Analysis of DNA Methylation in Arabidopsis. Cell, 126, 1189-1201. http://dx.doi.org/10.1016/j.cell.2006.08.003

Zhong, L., Xu, Y., \& Wang, J. (2009). DNA-methylation changes induced by salt stress in wheat Triticumaestivum. African Journal of Biotechnology, 8. Retrieved from http://www.ajol.info/index.php/ajb/article/view/66122

\section{Copyrights}

Copyright for this article is retained by the author(s), with first publication rights granted to the journal.

This is an open-access article distributed under the terms and conditions of the Creative Commons Attribution license (http://creativecommons.org/licenses/by/3.0/). 